\title{
Supportive care framework
}

by Margaret I. Fitch

\section{Abstract}

The Supportive Care Framework for Cancer Care was originally formulated in 1994 (Fitch, 1994). The framework was designed as a tool for cancer care professionals and program managers to conceptualize what type of help cancer patients might require and how planning for service delivery might be approached. The framework has been presented in various arenas and utilized in program and the number of requests has been growing for a wider distribution of a full description of the framework.

The purpose of this article is to share the Supportive Care Framework for Cancer Care with the cancer nursing community. As a conceptual framework, it may be a useful tool for service or program planning, a basis to organize educational approaches in cancer care, or as a model underpinning research projects.

\section{Introduction}

The Supportive Care Framework for Cancer Care was originally formulated in 1994 (Fitch, 1994). The framework was designed as a tool for cancer care professionals and program managers to conceptualize what type of help cancer patients might require and how planning for service delivery might be approached. Since that time, the framework has been presented and discussed in various arenas and utilized in program and policy planning (Fitch, 2000). Recently, the number of requests has been growing for a wider distribution of a full description of the framework in writing.

The purpose of this article is to share the Supportive Care Framework for Cancer Care with the cancer nursing community. As a conceptual framework, it may be a useful tool for service or program planning, a basis to organize educational approaches in cancer care, or as a model underpinning research projects. This manuscript outlines the theoretical underpinnings of the framework. A separate publication is in process to illustrate various applications of the framework.

\section{Background}

The initial thinking about the Supportive Care Framework in Cancer Care emerged from a task force established by the Ontario Cancer Treatment and Research Foundation (Fitch, 1994). The task force consisted of experts in the care of cancer patients and families and included a cross section of disciplines (nursing, systemic and radiation oncology, social work, psychology, pharmacy, volunteers and cancer survivors). The framework was built on the basis of the collective experience and expertise of these individuals and drawn from the broad ranging literature on adaptation and coping.

The concepts within the framework have been validated since that time through in-depth interviews with patients and survivors about their experiences with cancer, its treatment, and living with the aftermath of that treatment (Gould, James, Gray, \& Fitch, 2003; Gray, Greenberg, Fitch, Sawka, \& Hampson, 1998; Gray, Fitch, Davis, \& Phillips, 1997; Gray, Fitch, Phillips, \& Labrecque, 2000; Fitch, Deane, \& Howell, 2003); surveys with patients about their needs and satisfaction with the care they received (Ashbury, Findley, Reynolds, \& McKerracher, 1998); and discussions with cancer care providers about their experiences in meeting patients' needs (Supportive Care Steering Group, 2004; Fitch \& Turner, 2004). The concepts also appear regularly in the literature and have been the focus of research initiatives with increasing frequency over the last decade (National Cancer Institute of Canada [NCIC], 2005). Most recently, the concepts have been embedded within the Canadian Strategy for Cancer Control under an action group entitled, ReBalancing Focus Canadian Strategy for Cancer Control (CSCC, 2002). The action group has written a vision for a cancer care system that describes a system where resources are allocated in a balanced fashion so that care delivery is responsive, compassionate, comprehensive and person-centred. It is a system envisioned to have the capacity to respond to the supportive care needs of cancer patients and survivors.

The Supportive Care Framework is presented in this article together with references from the literature that will provide more in-depth reading. It is anticipated the framework could be useful to the individual practitioner in daily practice, as well as the program manager in designing and evaluating quality service delivery. The concepts inherent in the framework and its underlying philosophy provide a way of thinking about and conducting assessment with an individual patient and determining the interventions that ought to be considered for the plan of care. The concepts can also serve as a guide for making decisions about the range of services that ought to be available to cancer patients and their families. They may also be used as a frame to guide educational and research programs.

\section{Supportive care framework}

The Supportive Care Framework for Cancer Care draws upon the constructs of human needs, cognitive appraisal, coping and adaptation as a basis for conceptualizing how human beings experience and deal with cancer. Each of these aspects and their application to the cancer experience will be highlighted.

\section{Human needs}

Human beings are more than physical entities. They also have emotional, psychological, social and spiritual aspects. Human beings take action throughout each day to ensure their needs in each of these domains are fulfilled (Maslow, 1998). They eat, rest, sleep, work, play, and develop ways of coping with the world and the changes that happen. As human beings grow to adulthood, they develop a repertoire of skills to care for themselves and meet their own needs.

As life events occur and changes unfold, there may be times when the usual way of meeting daily needs is not effective (Dudas \& Carlson, 1988). A person's needs cannot be met in the same manner or by using the routine approaches. A situation may arise that creates new demands, and anxieties can begin to emerge. Feelings of vulnerability can unfold together with a sense of loss of control over a situation and uncertainty about what to do. The individual may have to access new information, learn new skills, or seek help from others to meet their needs. These actions can be challenging in times of distress and add to the burden people experience (Taylor, 1983). If needs remain unmet, individuals continue to feel emotional distress and experience difficulty.

Margaret Fitch, RN, PhD, Toronto Sunnybrook Regional Cancer Centre,Toronto,ON, E-mail: marg.fitch@sunnybrook.ca 


\section{Cognitive appraisal}

Individuals frequently vary widely in their response to a particular event or life situation. No two individuals will respond to a situation in exactly the same way. The variation in human response is a function of the individuals' cognitive appraisal of the situation (Lazarus \& Folkman, 1984; Park \& Folkman, 1997; Folkman \& Greer, 2000). Cognitive appraisal is the process whereby an individual thinks about and categorizes an event, and its various aspects, and judges its effect on his or her well-being. It is largely an evaluative process, focused on meaning, and occurs constantly during waking hours. When confronted with an event, an individual engages in primary appraisal. He or she judges the event as irrelevant, benign, positive, or stressful by answering the question, "Am I in trouble or will I benefit, now or in the future?" Secondary appraisal involves answering the question, "What can be done about this situation?" These appraisals can be conscious or unconscious. They are influenced by factors such as an individual's existing knowledge, past experiences, self-concept, needs, attitudes, culture, and life goals. The individual judges the situation or attaches meaning to the situation using his or her own individual perspective (cognitive map) and personal ideas or beliefs about what is important. Subsequent emotional responses emerge. Behaviour

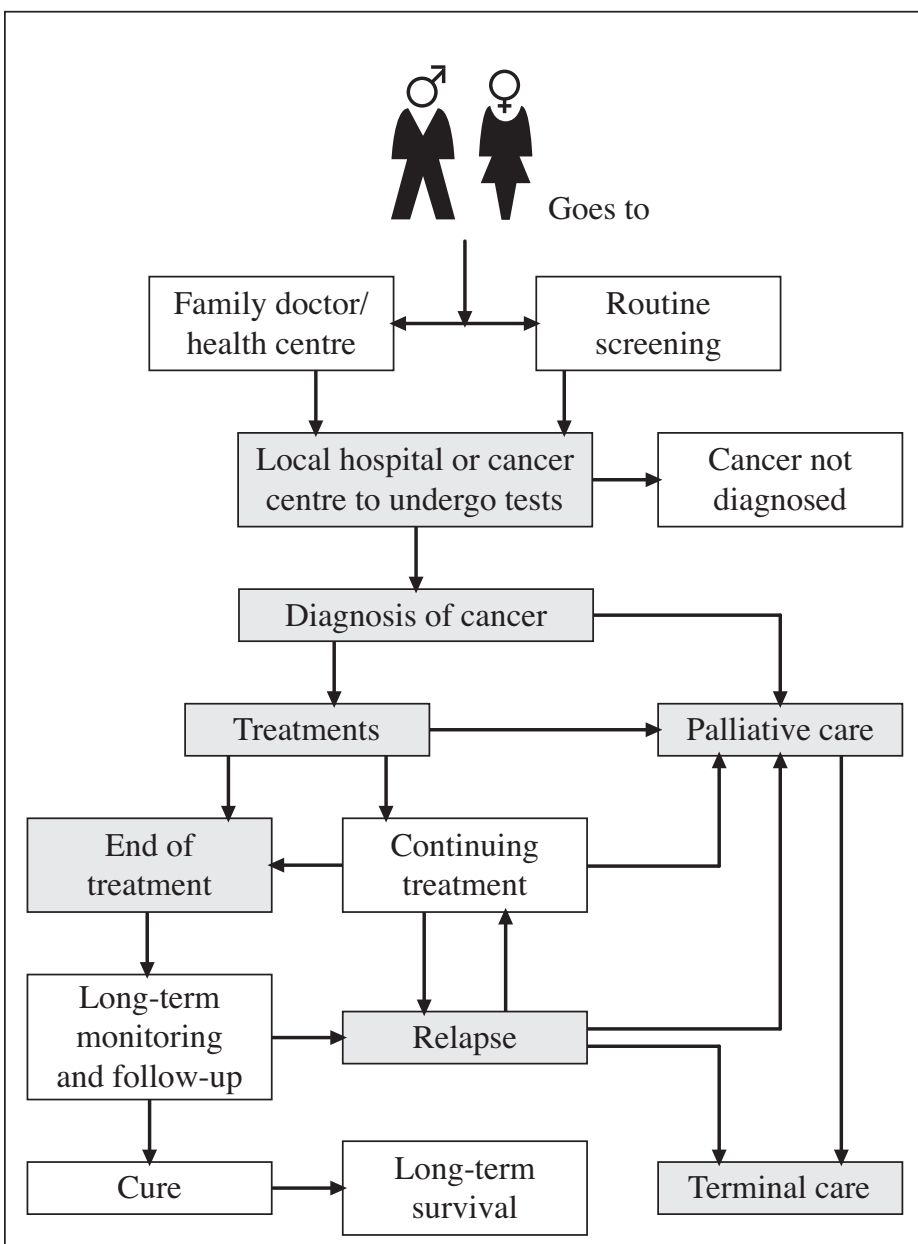

Key points in

the cancer journey

Supportive care is provided at all stages of the pathway from pre-diagnosis onwards results on the basis of the person's appraisal about how much and what type of threat exists, in view of their capacity to do what they perceive is required by the situation. If the person concludes there is little they can do to remove, minimize, or counteract the threat to themselves, emotional distress escalates.

\section{Coping and adaptation}

Coping may be conceptualized as all an individual does in order to deal with and manage an event or situation and its inherent emotional distress (Pearlin \& Schooler, 1978). It is an ongoing dynamic process that occurs similarly with regard to daily hassles or to life-threatening events. Human beings use a wide variety of coping strategies as they move through their daily lives, working to meet their needs and maintain a sense of well-being in an ever-changing environment. These coping strategies can be categorized on the basis of the purpose they serve: 1) problem-solving: managing or altering the situation (problem) causing the distress, and 2) emotion-focused: regulating the emotional response to the situation (Lazarus \& Folkman, 1984; Parker \& Endler, 1996). The selection of coping strategies in a particular situation is based on the individual's appraisal or perceived meaning of that situation.

Predicting the specific combination of coping strategies a particular individual will use in a selected situation is difficult (Pearlin \& Schooler, 1978; Folkman \& Moskowitz, 2000). It is clear that individuals may select the same strategies for a variety of situations, yet select different strategies for the same situation at different points in time. Even in the same situation, different people will exhibit different reactions and select different coping strategies. The key to understanding a specific person's behavioural and emotional response is to understand that person's interpretation or appraisal of the situation. People respond to their perspective about the meaning the situation has for them.

In general, overall adjustment is linked with four personal resources: a) a capacity to see change as an opportunity and challenge, b) to shift coping strategies and use alternative ones when the usual ones are not working, c) to identify those aspects of the event where personal control can be achieved, and d) to access required resources (Bjorck, Hopp, \& Jones, 1999; Thompson \& Collins, 1995; Pollock, Christian, \& Sands, 1990). Adjustment to life events is a process that unfolds over time and can be influenced by factors such as social support, available resources, and access to information. Effective adjustment implies an adaptation to the environment (physical and social), successful accomplishment of the tasks (demands) associated with growth and development, and management of the problems or demands within life situations.

Given the changing nature of needs, the variation in human response to both everyday living and to unexpected events, and the complexity of coping behaviours, it can be a challenge to find the pathway to assist a person or intervene to help a person cope. The person's desired goals or anticipated outcomes may be unique. Yet, success regarding the outcome of any intervention is best judged on the basis of the individual's desired goals and values (Lazarus \& Folkman, 1984). Interventions will need to be matched or tailored according to these individual goals and values as a frame of reference. Although outcomes may be defined or labelled in a universal or common fashion (e.g., quality of life, satisfaction, well-being, optimal function), the specific interpretation of an outcome is apt to vary from person to person. What may be required and useful for one person may be different for another. For example, one person likes to talk with others to learn about how to cope with a situation while someone else would rather read in order to learn the same thing. Also, a person may prefer to gather support by attending a peer support group and another accesses that support over a long-distance telephone call. It is critically important to explore with the individual the options for intervention, desire for 
assistance, and how best to provide the required assistance. Such an exploration or person-centred conversation may have to be repeated over time.

\section{Cancer as an unexpected life event}

The diagnosis and treatment of cancer can be conceptualized as an unexpected life event or series of events across a spectrum of experience with a disease. Cancer may be experienced as a single event for some individuals with a defined beginning and ending. For others, the cancer experience may take on a chronic nature. For all, there is a spectrum of events and interactions with the cancer care system from pre-diagnosis, through diagnosis, treatment and followup. Depending upon the situation, follow-up may encompass longterm survivorship, recurrence of the disease, or death because of the disease.

Individuals may enter the cancer care system at various points and move through a spectrum of experiences at different paces and along different pathways (See Figure One). Some will enter at the point of screening and may never proceed any further. Others will enter at the point of diagnosis and move through phases of treatment, rehabilitation and follow-up. Some of those in follow-up will continue without any further clinical evidence of cancer, while others will experience recurrent disease. Additionally, some individuals will enter at the point of diagnosis, but require palliative care immediately. Finally, death as a result of cancer remains the final outcome for about half of those diagnosed with the disease (NCIC, 2007). For some, death occurs a relatively short time following diagnosis; for others, death may follow many years of living with the illness.

From the moment an individual thinks there might be something wrong with their body, throughout the course of the diagnostic investigation, treatment and follow-up care, the experience of living with cancer is a continuous one for that person and family (Howell, Fitch, \& Deane, 2003). The cancer-related events are embedded in their daily lives. The illness-related demands become part of every day living and decision-making. Cancer often becomes an everpresent spectre, not a separate entity that can easily be set aside and ignored. The cancer-related events are connected one to the other for the person and the family members. What has happened before influences what happens later; their journey is a continuous one.

\section{Cancer has more than a physical impact}

Cancer and its treatment have an impact on individuals that is felt in a number of ways. In addition to physical changes, cancer may evoke emotional, social, psychological, economic, and spiritual changes (Canadian Cancer Society, 1992; Ashbury et al., 1998; Canadian Cancer Society, 2003). Dealing with these changes creates a myriad of issues and challenges for an individual with the disease and their family members. Various reactions emerge: shock, disbelief, confusion, sadness, anger, relief and resignation (Canadian Association of Psychosocial Oncology, 2003). Many will say that life is never the same once they have heard the word "cancer". Some individuals confront their diagnosis successfully using familiar coping methods, while others find these usual approaches are not helpful. Some manage the challenges they face rather well, while others experience ongoing difficulties and distress. No two will exhibit the exact same reactions to the circumstances surrounding their cancer experience, even within the same family, but none will be unaffected (Kristjanson \& Ashcroft, 1994; Yates, 1999).

\section{Individuals diagnosed with cancer and} their families have a wide range of needs

When a cancer illness strikes, a person's ability to meet his or her own needs may be compromised. Physical discomfort or a sense of personal crisis may interfere with an individual's usual approaches to meeting his or her needs. Additionally, when a person is facing lifethreatening illness, specific issues emerge as that individual contemplates notions about the meaning of life and his or her own mortality (see Figure Two).

As individuals and their family members live through their cancer journey, they experience physical, emotional, social, psychological, spiritual, informational and practical changes that impact on the needs that are experienced. Numerous studies have described the changing needs of cancer patients (see Table One). These specific needs will vary from person to person and within the same person over time, as the course of the disease and treatment unfolds. The nature of each need can also change over time and the intensity of the impact often varies throughout the illness (Fitch, 2000). For example, early in the course of illness, the need for medical information is high; the need for emotional and spiritual support may be relatively constant throughout the course of the illness; and the need for pain and symptom control may predominate as the disease progresses. Although the stage of disease and type of treatment influence the physical symptoms with which an individual must cope, the symptoms are not necessarily linked to the intensity of the emotional distress a person experiences (Zabora, Blanchard, \& Smith, 1997). For some, emotional distress can continue long after there is no clinical evidence of cancer.

Whether or not a person is able to meet his or her own needs during a cancer experience is influenced by a variety of factors. Physical discomfort or disability, emotional distress, or a sense of personal crisis may interfere with an individual's capacity to act (Bury, 1982; Folkman \& Greer, 2000; Zabora et al., 1997). The usual ways of meeting one's daily needs may be compromised and new knowledge, new skills, or different supports may be required to manage with the demands of the cancer situation. However, seeking information, learning new skills, or reaching out to other people may be difficult when the stresses of the cancer experience emerge. Living with unmet needs adds to the burden of suffering and emotional turmoil a cancer

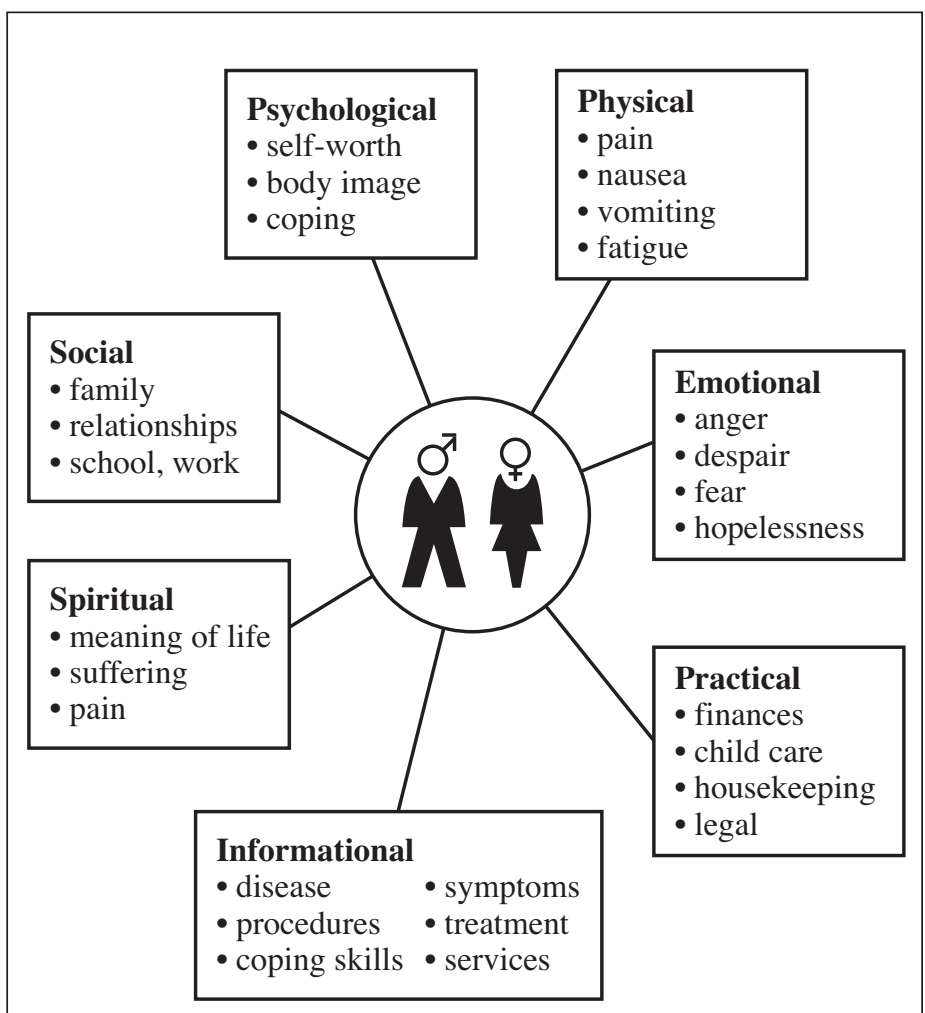

Figure Two. Examples of needs of individuals living with cancer 
patient experiences (David, 1999; Gray, 2003; Charmaz, 1991; McLean, 1993; Phillips, 1998; Rosenbaum, 1982; Weisman, 1979).

\section{Emotional distress is an expected response to illness}

Emotional or psychosocial distress is a natural or expected response to life-threatening illness. It is experienced by all cancer patients to some degree. Even those who are able to mobilize their own resources and cope effectively will experience emotional upheaval with this diagnosis. The individuals who are not able to find a way to meet their needs will experience ongoing and escalating emotional distress. The emotional distress can escalate to significant levels where it can compromise adherence to therapy, increase utilization of other health care services, and elevate costs for care (Holland, 1999; Browne, Arpin, Corey, Fitch, \& Gafni, 1990; Zabora, BrintzenhofeSzoc, Curbow, Hooker, \& Piantadosi, 2001).
As many as $35 \%$ of a mixed group of cancer outpatients exhibit significant emotional distress or a level of distress at which they could benefit from intervention from professional counsellors (Zabora et al., 2001). When patients are grouped on the basis of stage of disease, the prevalence of significant psychosocial distress can vary. In one study, $39 \%$ of those on active treatment experienced significant psychosocial distress, while $79 \%$ of those receiving palliative care and $17 \%$ of those who did not have clinical evidence of disease experienced similar levels (Fitch, Vachon, Greenberg, \& Franssen, 1996). The presence of psychosocial distress itself, however, does not reveal the reason for the distress or necessarily point to a specific course of intervention. The reason for the distress and the person's desire for assistance must be uncovered through dialogue with the person prior to establishing the appropriate intervention(s).

\section{Table One. Defining needs of individuals living with cancer: Categories of needs and examples}

\begin{tabular}{|c|c|c|c|}
\hline Definition of Need Categories & \multicolumn{3}{|c|}{ Specific Examples of Supportive Care Symptoms and Needs in Cancer } \\
\hline $\begin{array}{l}\text { Physical } \\
\text { Needs for physical comfort and freedom } \\
\text { from pain, optimum nutrition, ability to } \\
\text { carry out one's usual day-to-day functions } \\
\text { (i.e., activities of daily living) }\end{array}$ & $\begin{array}{l}\text { - pain } \\
\text { - weakness } \\
\text { - fatigue } \\
\text { - anorexia } \\
\text { - nausea } \\
\text { - vomiting } \\
\text { - mobility } \\
\text { - lymphedema }\end{array}$ & $\begin{array}{l}\text { - incontinence } \\
\text { - thirst } \\
\text { - cough } \\
\text { - shortness of breath } \\
\text { - spitting up blood } \\
\text { - loss of appetite } \\
\text { - hair loss }\end{array}$ & $\begin{array}{l}\text { - impotence } \\
\text { - changes in bowel habits } \\
\text { - difficulties with diet/fluid intake } \\
\text { - difficulties with sleeping } \\
\text { - weight changes } \\
\text { - menopause } \\
\text { - difficulties swallowing/speaking } \\
\text { - fertility }\end{array}$ \\
\hline $\begin{array}{l}\text { Informational } \\
\text { Needs for information to reduce } \\
\text { confusion, anxiety and fear; to inform the } \\
\text { person's or family's decision-making; } \\
\text { and to assist in skill acquisition }\end{array}$ & $\begin{array}{l}\text { - cancer treatment and side } \\
\text { effects procedures/test results } \\
\text { - how to handle or } \\
\text { manage side effects } \\
\text { - care processes }\end{array}$ & \multicolumn{2}{|c|}{$\begin{array}{l}\text { - communication with caregivers } \\
\text { - orientation to treatment facility } \\
\text { - educational resources (appropriate) } \\
\text { - help with decision-making }\end{array}$} \\
\hline $\begin{array}{l}\text { Emotional } \\
\text { Needs for a sense of comfort, belonging, } \\
\text { understanding and reassurance in times } \\
\text { of stress and upset }\end{array}$ & $\begin{array}{l}\text { - fear } \\
\text { - distress } \\
\text { - anxiety } \\
\text { - depression } \\
\text { - anger }\end{array}$ & $\begin{array}{l}\text { - guilt } \\
\text { - grief } \\
\text { - abandonment } \\
\text { - hopelessness }\end{array}$ & $\begin{array}{l}\text { - to talk with a peer } \\
\text { - powerlessness } \\
\text { - shame/self-blame } \\
\text { - isolation }\end{array}$ \\
\hline $\begin{array}{l}\text { Psychological } \\
\text { Needs related to the ability to cope } \\
\text { with the illness experience and its } \\
\text { consequences, including the need } \\
\text { for optimal personal control and } \\
\text { the need to experience positive } \\
\text { self-esteem }\end{array}$ & $\begin{array}{l}\text { - changes in lifestyle } \\
\text { - sexual problems } \\
\text { - diminished cognitive ability } \\
\text { - loss }\end{array}$ & \multicolumn{2}{|c|}{$\begin{array}{l}\text { - loss of personal control } \\
\text { - major depression } \\
\text { - anxiety disorders } \\
\text { - self-image problems } \\
\text { - body image changes } \\
\text { - fear of recurrence }\end{array}$} \\
\hline $\begin{array}{l}\text { Social } \\
\text { Needs related to family relationships, } \\
\text { community acceptance and involvement } \\
\text { in relationships }\end{array}$ & \multicolumn{3}{|c|}{$\begin{array}{l}\text { - changes in roles } \\
\text { - difficulty dealing with the responses of family members/children } \\
\text { - social relationships } \\
\text { - interpersonal communication } \\
\text { - telling other people }\end{array}$} \\
\hline $\begin{array}{l}\text { Spiritual } \\
\text { Needs related to the meaning } \\
\text { and purpose in life to practice } \\
\text { religious beliefs }\end{array}$ & $\begin{array}{l}\text { - search for meaning } \\
\text { - existential despair }\end{array}$ & \multicolumn{2}{|c|}{$\begin{array}{l}\text { - examine personal values, priorities } \\
\text { - spiritual crisis/resolution } \\
\text { - feelings of hopelessness }\end{array}$} \\
\hline $\begin{array}{l}\text { Practical } \\
\text { Needs for direct assistance in order } \\
\text { to accomplish a task or activity and } \\
\text { thereby reduce the demands on the } \\
\text { person (e.g., homemaking services, } \\
\text { financial assistance) }\end{array}$ & $\begin{array}{l}\text { - daily home help } \\
\text { - shopping } \\
\text { - transportation } \\
\text { - child care } \\
\text { - prosthesis } \\
\text { - travel to and from } \\
\text { treatment appointments }\end{array}$ & \multicolumn{2}{|c|}{$\begin{array}{l}\text { - assistance in activities of daily living } \\
\text { - provision of family relief } \\
\text { - stresses involving family, children, parents, etc. } \\
\text { - financial issues } \\
\text { - legal issues } \\
\text { - employment issues/school issues } \\
\text { - menu planning/food preparation }\end{array}$} \\
\hline
\end{tabular}


Assisting individuals who are living

with cancer requires tailored interventions

Finding the best method for assisting cancer patients to meet their needs means tailoring interventions. The intervention, or set of interventions, that may be helpful to one person will not necessarily be helpful to another. The interventions for each cancer patient must be matched to that individual's personal needs, desired goals, and ways of coping. Coping with life-threatening illness and adapting to its aftermath is influenced by an individual's perception of the situation, as well as a myriad of factors such as socio-economic status, educational background, social support, culture, religion, and geographical location. People also learn in different ways and have various capacities to live with uncertainty and emotional distress. Some will want assistance while others will not. And some may decline assistance at one time, but accept it at another.

The interventions offered to assist individuals must be based on careful assessment of the individual's need in each need domain and tailoring of the specific intervention approaches. The tailoring of an intervention, and the subsequent evaluation of its success, must be based on the individual patient's own frame of reference and desired goals (e.g., has the intervention been tailored sufficiently to attend to the unique situation and personality factors, the given specific event, for this particular individual?). For example, women assign a different importance to information than do men and young women desire different types of supports than older women (Fitch, 2007). Outcomes must be defined by incorporating the patient perspectives. They must not be based solely on the health care provider perspectives about what ought to happen.

Communication and the provision of information are key aspects in the assessment of situations and identification of appropriate interventions. Communication with a patient will be influenced by factors such as cultural norms and practices, attitudes toward the health care system and its providers, and past experiences with health care and with cancer (Muzzin, Anderson, Figueredo, \& Gudelis, 1994). The way communication occurs between health care providers and patients can be perceived as supportive and helpful or be seen as an added burden (Bakker, Fitch, Gray, Reed, \& Bennett, 2001). During times of distress, individuals may not hear or be able to recall information that is provided. Additionally, some individuals will want detailed information while others will not; all can feel overwhelmed with the amount of information there is to know and the scientific language utilized. Fundamentally, cancer patients want to know something about the disease, treatment options, likely prognosis and available resources (Luker, Beaver, Lenster, \& Owens, 1996). Information is a key to informed decision-making, but individuals will differ in their desire for active involvement in decision-making about their care (Hack, Degner, \& Dyck, 1994; Davison, Degner, \& Morgan, 1995; Davison \& Degner, 1997).

Table Two summarizes evidence about the proportion of cancer patients who could require assistance in each of the need domain areas. The site and stage of cancer and the treatment modality influence the type of issues patients have to face. For example, colorectal cancer treated with surgery may mean the individual must learn to cope with a colostomy, leukemia may mean coping with bone marrow transplantation. A dialogue with the person is needed to identify the specific issues that individual is concerned about and the ones $\mathrm{s} / \mathrm{he}$ would like help with managing. It is important to acknowledge that not all patients want help with an issue despite being concerned about them (Fitch \& Steele, 2003). Without a focused person-centred conversation about what types of help a person wants, the care provided could be inappropriate. The patient and the health care

Table Two. Proportion of cancer patients needing various types of assistance ${ }^{1,2}$

\begin{tabular}{|c|c|}
\hline Type of Need & Proportion of Cancer Patients Needing Assistance \\
\hline $\begin{array}{l}\text { Pain/Symptom Distress } \\
\text { (Physical) }\end{array}$ & $\begin{array}{l}\text { The proportion of patients experiencing difficulties with pain/symptoms will vary depending on the site and } \\
\text { the stage of disease. In three Canadian studies of needs of cancer outpatients the following proportions were } \\
\text { observed for the most frequently identified symptoms in the past month: fatigue } 28 \%-40 \% \text {; pain } 21 \%-32 \% \text {; } \\
\text { sleep disturbances } 16-33 \% \text {; nausea } 19 \%-31 \% \text {. }\end{array}$ \\
\hline Emotional & $\begin{array}{l}\text { All patients require some level of emotional support. The challenge lies in linking the individual with } \\
\text { the type of support that is best for them (i.e., peer, group, professional). }\end{array}$ \\
\hline $\begin{array}{l}\text { Cognitive } \\
\text { Psychosocial } \\
\text { Spiritual }\end{array}$ & $\begin{array}{l}20 \%-30 \% \text { of cancer patients experience significant psychosocial distress and would benefit from } \\
\text { professional intervention. The source of distress is not evident until an assessment is conducted. } \\
\text { Issues may exist regarding changes in body image, self-esteem, faith, life meaning, despair, guilt, etc. }\end{array}$ \\
\hline Nutritional & $\begin{array}{l}\text { Between } 31 \%-87 \% \text { of patients experience weight loss during treatment. Weight loss is a major } \\
\text { prognostic indicator of survival and response to treatment. Between } 47 \%-61 \% \text { of patients required } \\
\text { intervention by a dietitian. }\end{array}$ \\
\hline Speech Therapy & All patients undergoing surgery where swallowing is compromised, because speech could be influenced. \\
\hline $\begin{array}{l}\text { Practical Assistance: } \\
\text { Transportation, } \\
\text { Day Care, } \\
\text { Legal, Finances }\end{array}$ & $\begin{array}{l}\text { These issues very much dependent on the age of the individual as well as family and financial situation. They } \\
\text { could include issues concerning work, household responsibilities, school, child care, respite care, etc. }\end{array}$ \\
\hline Information & $\begin{array}{l}\text { All patients require some level of information. The challenge lies in creating a comfortable environment for } \\
\text { dialogue and providing opportunities for patients to ask questions. Information is needed about cancer, care } \\
\text { processes, symptoms, procedures, treatment, coping skills, services available, etc. }\end{array}$ \\
\hline Mental Illness & $\begin{array}{l}10 \%-20 \% \text { of all oncology patients suffer from major illness such as a major depression, anxiety } \\
\text { disorder, delirium or dementia. Successful treatment of major depression will likely require medication. }\end{array}$ \\
\hline
\end{tabular}


provider need to work as partners, and be clear about the goals or outcomes they are trying to reach. In a practice environment, this means the assessment process must identify expectations and goals held by the individual, across all need areas, within an existing situation, and then tailor the intervention plan to those parameters in collaboration with the person. This process of assessment, mutual goal setting, and tailoring interventions is necessary throughout the course of a cancer patient's journey to reduce unnecessary emotional distress and enhance a person's capacity to cope effectively (Fitch, 2003; Zabora, Loscalzo, \& Weber, 2003).

\section{Supportive care defined}

Supportive care is defined as the provision of the necessary services for those living with or affected by cancer to meet their physical, emotional, social, psychological, informational, spiritual and practical needs during the diagnostic, treatment, and follow-up phases, encompassing issues of survivorship, palliative care and bereavement (Fitch, 1994).

Supportive care embraces the full range of issues/challenges that emerge for an individual as s/he experiences the impact of the diagnosis of cancer and its treatment and tries to cope with the aftermath. In other words, it is an overarching concept to describe all the help cancer patients and their families may need beyond their medical, surgical or radiation interventions. Supportive care interventions, regardless of their diversity or who provides them, are aimed toward helping the individual cope with what is happening and maintaining that person's quality of life. Supportive care seeks to improve and preserve the quality of life, autonomy and dignity of those living with, and affected by, the cancer. It is aimed toward empowerment and optimizing wellness.

To be effective, supportive care must be based upon, and matched with, an individual's needs within the context of his or her unique situation. Supportive care interventions must be tailored to the individuals' frame of reference and desired goals. An individual patient's needs must determine the nature of the supportive care provided, not merely the desires of the health care provider. The central notion driving the choice of intervention is one of working in concert with the individual and identifying the specific approaches required to meet that person's unique needs.

\section{Table Three. Supportive care program model: All services may not be available in one clinical setting; partnerships between formal cancer programs and community-based agencies may be required to provide early access for patients/families to the full range of services}

\begin{tabular}{|c|c|c|c|}
\hline Service or Activity & Target Group for Service & Purpose of Service & $\begin{array}{l}\text { Leadership in } \\
\text { Offering Service }\end{array}$ \\
\hline $\begin{array}{l}\text { Orientation/Ongoing } \\
\text { Patient and Family } \\
\text { Education }\end{array}$ & $\begin{array}{l}\text { All new patients/ } \\
\text { family members }\end{array}$ & $\begin{array}{l}\text { To introduce the cancer centre, cancer care } \\
\text { and the cancer system; to offer information about } \\
\text { resources; to provide links to contacts to follow-up }\end{array}$ & $\begin{array}{l}\text { Staff/Patients/ } \\
\text { Volunteers }\end{array}$ \\
\hline $\begin{array}{l}\text { Emotional Support } \\
\text { and Peer Information } \\
\text { (i.e., Reach to Recovery } \\
\text { Visiting, Cansurmount, } \\
\text { Self-Help Groups) }\end{array}$ & $\begin{array}{l}\text { Individuals who wish to talk with } \\
\text { another patient either in a group } \\
\text { setting or on a one-to-one basis }\end{array}$ & $\begin{array}{l}\text { To provide an opportunity to talk with other cancer } \\
\text { patients about their experiences, feelings, concerns; } \\
\text { to share experiences and information on a peer basis }\end{array}$ & $\begin{array}{l}\text { Cancer Patients/ } \\
\text { Volunteers }\end{array}$ \\
\hline $\begin{array}{l}\text { Psycho-Educational } \\
\text { (maybe a group } \\
\text { experience or one-to-one } \\
\text { experience) }\end{array}$ & $\begin{array}{l}\text { Individuals who find they want to } \\
\text { learn new coping skills; express } \\
\text { difficulty coping with the cancer } \\
\text { experience }\end{array}$ & $\begin{array}{l}\text { To provide an opportunity to learn coping skills } \\
\text { and problem-solving skills regarding issues } \\
\text { confronting them }\end{array}$ & $\begin{array}{l}\text { Professionally } \\
\text { Trained Group } \\
\text { Leaders }\end{array}$ \\
\hline $\begin{array}{l}\text { Adjustment/Supportive } \\
\text { Counselling }\end{array}$ & $\begin{array}{l}\text { Individuals who require help to } \\
\text { adjust to their diagnosis and } \\
\text { treatment }\end{array}$ & $\begin{array}{l}\text { To provide regular assistance/support for individuals } \\
\text { during their treatment }\end{array}$ & Professional \\
\hline $\begin{array}{l}\text { Crisis Intervention } \\
\text { (one-to-one) }\end{array}$ & $\begin{array}{l}\text { Individuals requiring immediate } \\
\text { intervention regarding emotional, } \\
\text { spiritual or psychosocial distress }\end{array}$ & $\begin{array}{l}\text { To provide immediate intervention focused on } \\
\text { managing or resolving emotional/psychosocial } \\
\text { distress }\end{array}$ & Professional \\
\hline $\begin{array}{l}\text { Psychotherapy } \\
\text { - short term } \\
\text { - long term }\end{array}$ & $\begin{array}{l}\text { Individuals requiring ongoing } \\
\text { intervention regarding emotional, } \\
\text { spiritual or psychosocial distress }\end{array}$ & $\begin{array}{l}\text { To provide ongoing and in-depth intervention } \\
\text { focused on managing or resolving emotional/ } \\
\text { psychosocial distress }\end{array}$ & Professional \\
\hline Nutritional Intervention & $\begin{array}{l}\text { Individuals who want advice } \\
\text { regarding nutrition; who are } \\
\text { experiencing difficulties } \\
\text { regarding eating }\end{array}$ & $\begin{array}{l}\text { To provide advice regarding nutrition/ intervention } \\
\text { for those with eating difficulties }\end{array}$ & Nutritionist \\
\hline $\begin{array}{l}\text { Pain/Symptom } \\
\text { Management }\end{array}$ & $\begin{array}{l}\text { Individuals experiencing } \\
\text { difficulties with management } \\
\text { of pain or other symptoms } \\
\text { (i.e., lymphedema, fatigue) }\end{array}$ & To reduce or eliminate distress due to symptoms & $\begin{array}{l}\text { Professional (i.e., } \\
\text { doctor, nurse, etc.) }\end{array}$ \\
\hline $\begin{array}{l}\text { Practical and } \\
\text { Functional Assistance }\end{array}$ & $\begin{array}{l}\text { Individuals who require help with } \\
\text { activities of daily living, child } \\
\text { care, financial assistance, } \\
\text { transportation, etc. }\end{array}$ & $\begin{array}{l}\text { Service designed to assist with practical matters } \\
\text { (may only focus on one of these areas) and achieve } \\
\text { optimal physical functioning }\end{array}$ & $\begin{array}{l}\text { Staff/Volunteers } \\
\text { (depending on } \\
\text { program) } \\
\text { Professional }\end{array}$ \\
\hline
\end{tabular}




\section{Providing supportive care}

Supportive care embraces the notion that a range of expertise is needed to provide comprehensive care to cancer patients and their family members. Supportive care is not the prerogative of one discipline or agency. Aspects of supportive care must be integral to the practice of all health care professionals and demonstrated in actions such as offering the patient emotional support, providing information in the course of interactions, and referring patients to other providers as necessary. In addition to the supportive care provided to patients and families by oncologists, nurses, radiation therapists and pharmacists, a full supportive care program includes the services of other individuals such as:

Professional: social workers, psychologists, family physicians, palliative care physicians, clergy/chaplains, nutritionists, specialty nurses, physiotherapists, occupational therapists, speech therapists, and therapists in the fields such as art, music and touch;

Volunteers: who offer peer support, transportation, and practical aid.

Cancer patients receive care in many settings; inpatient, outpatient, physician offices, screening centres, and homes. Supportive care may be required in any or all of these settings and is necessary throughout the cancer journey. For the patient and family to receive appropriate supportive care in a timely fashion, there must be a network of agencies or organizations, professional and volunteer, working collaboratively to provide the full range of services. Without a coordinated approach between and among all the agencies that provide supportive cancer care, patients and families will not experience a seamless care experience, or timely access to supportive care services. Overall coordination of services ought to place the patient and family at the centre of a network of services and information.

Basic standards for supportive care of cancer patients and family members have been developed and are applicable for all cancer programs (Fitch, 1994). The standards can be used to design programmatic approaches or evaluate how services are operating (i.e., provide benchmarks). The five clinical standards are as follows:

- All individuals receive ongoing supportive care assessment

- All individuals have the opportunity to be referred to an appropriate supportive care resource

- All individuals have the opportunity for self-referral to supportive care resources

- All individuals have access to understandable, relevant information regarding the medical, practical and emotional aspects of their cancer and its treatment; and

- All individuals receive supportive care that is relevant to their needs and sensitive to their age, gender, language, culture, sexual preferences, religion and economic status.

Table Three provides a description of the types of services that could benefit cancer patients and their family members, the purpose of the service, and who might be involved in providing it. The services that comprise a comprehensive model for supportive care may not need to be available in one clinical setting. Services could be

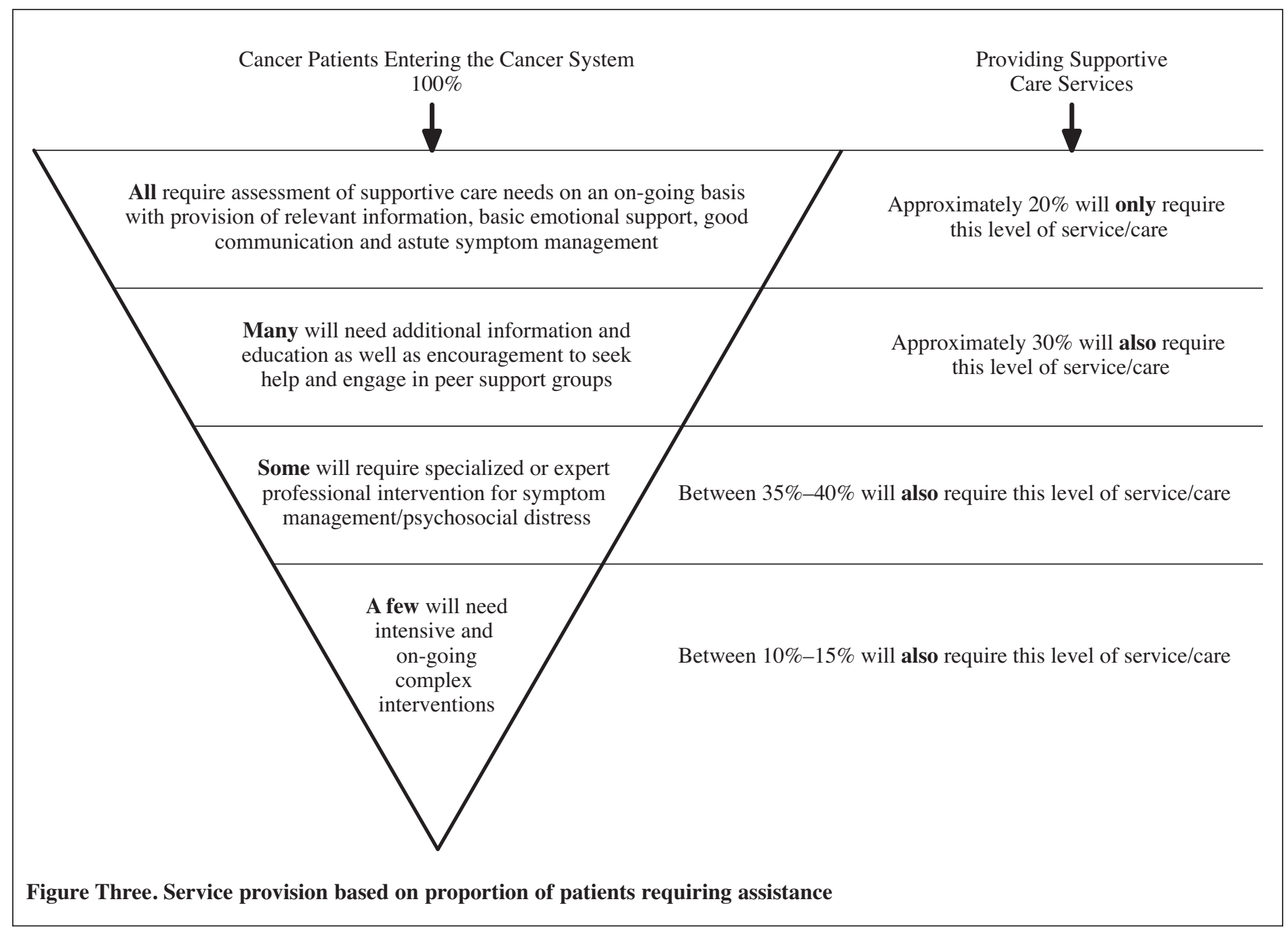


offered by several agencies working together across a region or geographical area. Regardless of where the actual services are offered, the fundamental challenge is to ensure that patients and family members know about the services and that there is easy access for them at the time they require the service.

Figure Three presents a way of conceptualizing service provision based on the proportion of patients who may require certain types of assistance.

\section{Implications for action}

Over the past decade, patient forums (Canadian Cancer Society, 1997; Health Canada, 1993; National Ovarian Cancer Association, 1999) and stakeholder meetings (Canadian Strategy for Cancer Control, 2002; 2005; National Ovarian Cancer Association, 2003-4) have produced reports describing shortcomings in the provision of supportive care for cancer patients and their family members. A recent national survey of ambulatory cancer patients about their satisfaction with care revealed their greatest concerns were with the provision of information and emotional support (Fitch \& Green, 2005). Both patients and survivors have made passionate calls for improvements in the cancer system. The types of improvements that could offer better access to supportive care include the following:

- Incorporating mechanisms and processes that allow:

basic supportive care assessment/information/support/referral to other services as appropriate

easy access to peer support and information (self-help and volunteer groups)

easy and proactive referral to specialized supportive care services

\section{References}

Ashbury, F.D., Findley, H., Reynolds, B., \& McKerracher, K. (1998). A Canadian survey of cancer patient experiences: Are their needs being met? Journal of Pain and Symptom Management, 6(5), 298-306.

Bakker, D.A., Fitch, M.I., Gray, R.E., Reed, E., \& Bennett, J. (2001). Patient health care provider communication during chemotherapy: The perspectives of women with breast cancer. Patient Education and Counselling, 43, 61-71.

Bjorck, J.P., Hopp, D.P., \& Jones, L.W. (1999). Prostate cancer and emotional functioning: Effects of mental adjustment, optimism, and appraisal. Journal of Psychosocial Oncology, 17(1), 71-85.

Browne, G.B., Arpin, K., Corey, P., Fitch, M., \& Gafni, A. (1990). Individual correlates of health service utilization and the cost of adjustment to cost adjustment to chronic illness. Medical Care, $18(1), 43-58$.

Bury, M. (1982). Chronic illness as biological disruption. Sociology of Health and Illness, 4(2), July, 167-82.

Canadian Association of Psychosocial Oncology. (2003). The emotional facts of life with cancer. Calgary, $A B$ :Author.

Canadian Cancer Society. (1992). The final report on the needs of persons living with cancer across Canada. Toronto: Author.

Canadian Cancer Society. (1997). Proceedings from the National Forum on Prostate Cancer, Toronto, ON. Toronto: Canada.

Canadian Cancer Society. (2003). Breaking down the barriers: Study of cancer patient and caregiver needs in Ontario. Toronto: Author.

Canadian Strategy for Cancer Control. (2002). Available www.partnershipagainstcancer.ca

Canadian Strategy on Cancer Control. (2002). Proceedings for national stakeholder forum. Toronto, Ontario.
- Implementing quality standards for supportive care, including psychosocial oncology, rehabilitative oncology and palliative care

- Implementing models with better organization, co-ordination and integration of supportive care that help patients and families navigate the cancer system

- Creating networks of providers with identified areas of concentration or roles for agencies

- Improving assessment of needs of cancer patients start with pain and distress indicators as a screening process

- Enhancing education of health care professionals in supportive care

- Enhancing service provision to meet patient demand for psychosocial oncology, rehabilitative oncology and palliative care; review who is providing services

- Promoting peer support/self-help communities actively (while working in partnership)

- Increasing research activity in supportive care topics and interventions

- Considering specific patient populations on which to focus key activities (e.g., patients needing intensive supportive care-lung, head and neck, newly diagnosed patients, those at end-of-life).

\section{Summary}

Individuals living with cancer must confront a myriad of challenges. Coping with these challenges can be overwhelming for patients and their family members. Some individuals will require assistance to manage with these challenges. Supportive care programs offer a way to assist patients and families with the full range of needs that may arise. Effective supportive care delivery requires the collaborative efforts of various disciplines and agencies working collaboratively with an integrated approach to person-centred compassionate cancer care.

Canadian Strategy on Cancer Control. (2005). Proceedings from national stakeholder forum. Aylmer, Quebec.

Charmaz, K. (1991). Good days, bad days: The self in chronic illness and time. New Brunswick, NJ: Rutgers University Press.

David, H. (1999). Coping with cancer: A personal odyssey. Patient Education and Counseling, 37, 293-297.

Davison, B.J., \& Degner, L.F. (1997). Empowerment of men newly diagnosed with prostate cancer. Cancer Nursing, 20(3), 187-96.

Davison, B.J., Degner, L.F., \& Morgan, T.R. (1995). Information and decision-making preferences of men with prostate cancer. Oncology, 22, 1401-8.

Degner, L.F., \& Sloan, J.A. (1995). Symptoms distress in newly diagnosed ambulatory cancer patients as an indicator of survival in lung cancer. Journal of Pain and Symptom Management, 10(6), 423-431.

Dudas, S., \& Carlson, C.E. (1988). Cancer rehabilitation. Oncology Nursing Forum, 15(2), 183-188.

Fitch, M.I. (1994). Providing supportive care for individuals living with cancer (Task Force Report). Toronto: Ontario Cancer Treatment and Research Foundation.

Fitch, M.I., Vachon, M., Greenberg, M., \& Franssen, E. (1996). Needs of cancer patients and their family members attending a comprehensive cancer centre. Paper presented in Conference Proceedings, 9th International Cancer Nursing Conference, Brighton, U.K., p. 68.

Fitch, M.I., Gray, R.E., DePetrillo, D., Franssen, E., \& Howell, D. (1999). Canadian women's perspectives on ovarian cancer. Cancer Prevention and Control, 3(1), 52-60.

Fitch, M.I. (2000). Supportive care for cancer patients. Hospital Quarterly, 3(4), 39-46. 
Fitch, M., Gowing, J., Murray, A., McKillop, I., Schertzer, L., Deane, K., \& Murray, M. (2002). Understanding supportive care needs over time: How well are we doing? 14th MASCC International Symposium, Supportive Care in Cancer, Boston, Massachusetts (June).

Fitch, M., Deane, K., \& Howell, D. (2003). Living with ovarian cancer: Women's experiences on treatment and treatment decisionmaking. Canadian Oncology Nursing Journal, 13(10), 8-13.

Fitch, M.I. (2003). Psychosocial management of patients with recurrent ovarian cancer: Treating the whole patient to improve quality of life. Seminars in Oncology Nursing, 19(3), 40-53.

Fitch, M.I., \& Steele, R. (2003). Supportive care needs of cancer patients: Looking beyond the obvious. Supportive Care Cancer, 11(6), 423.

Fitch, M.I., \& Turner, F. (2004). Canadian stakeholders' perspectives regarding priorities for information dissemination on ovarian cancer. 2nd National Conference on Ovarian Cancer. Ottawa, Canada (May).

Fitch, M., \& Green, E. (2005). Measuring patient satisfaction across the system. Supportive Care Cancer, 13(6), 472.

Fitch, M.I. (2006). Perspectives of older adults about the cancer information they receive. European Journal of Oncology Nursing, 10(3), 261-7.

Fitch, M.I. (2007). Young women's experiences with breast cancer: An imperative for tailored services. Oncology Nursing Forum, 34(2), 579 (abstract 2470).

Folkman, S., \& Greer, S. (2000). Promoting psychological well-being in the face of serious illness: When theory, research and practice inform each other. Psycho-oncology, 9, 11-19.

Folkman, S., \& Moskowitz, J.T. (2000). Positive effect and the other side of coping. America Psychology, 55(6), 647-54.

Gould, J., James, P., Gray, R.E., \& Fitch, M.I. (2003). Nothing fit me: Cross support needs of young women with breast cancer. PsychoOncology, 12(4), (Suppl), S146-7.

Gray, R.E. (2003). Prostate tales: Men's experiences with prostate cancer. Harriman, TN: Men's Studies Press.

Gray, R.E., Fitch, M.I., Davis, C., \& Phillips, C. (1997). A qualitative study of breast cancer self-help groups. Psychosocial Oncology, 6, 279-89.

Gray, R.E., Greenberg, M., Fitch, M.I., Sawka, C., \& Hampson, A. (1998). Information needs of women with metastatic breast cancer. Cancer Prevention and Control, 2(2), 57-62.

Gray, R.E., Fitch, M.I., Phillips, C., \& Labrecque, M. (2000). Managing the impact of illness: The experiences of men with prostate cancer and their spouses. Journal of Health Psychology, $5,525-42$.

Hack, T.F., Degner, L.F., \& Dyck, D. (1994). Relationship between preferences for decisional control and illness information among women with breast cancer: A quantitative and qualitative analysis. Social Science Medicine, 39, 279-289.

Health Canada (1993). Proceedings from the National Forum on Breast Cancer, Montreal, QC, Canada.

Health Canada (2002). Proceedings from the National Workshop on Palliative Care, Winnipeg, MB, Canada.

Holland, J.C. (1999). NCCN practice guidelines for the management of psychosocial distress. Oncology, 13(5A), 113-147.

Howell, D., Fitch, M.I., \& Deane, K. (2003). Women's experiences with recurrent ovarian cancer. Cancer Nursing, 26(1), 10-17.

Kristjanson, L.J., \& Ashcroft, T. (1994). The family's cancer journey: A literature review. Cancer Nursing, 17(1), 1-17.

Lazarus, R., \& Folkman, S. (1984). Stress, appraisal and coping. New York: Springer.

Luker, K.A., Beaver, K., Lenster, S.J., \& Owens, R.G. (1996). Information needs and sources of information for women with breast cancer: A follow-up study. Journal of Advanced Nursing, 23, 487-95.
Maslow, A.H. (1998). Toward a psychology of being (3rd ed.). Mississauga, ON: John Wiley \& Sons Canada Ltd.

McLean, G.L. (1993). Facing death: Conversations with cancer patients. London: Churchill Livingstone.

Muzzin, L.J., Anderson, J.J., Figueredo, A.T., \& Gudelis, S.O. (1994). The experience of cancer. Social Science \& Medicine, 38(9), 1201-8.

National Cancer Institute of Canada. (2007). Canadian cancer statistics 2007. Toronto: Author.

National Cancer Institute of Canada. (2005). Strategic plan-2005 report. Toronto: Author.

National Ovarian Cancer Association. (1999). Proceedings from 1st National Forum on Ovarian Cancer, Toronto, Ontario, Canada.

National Ovarian Cancer Association. (2003-4). Stakeholder forums across Canada. Toronto: Ovarian Cancer Information Project.

Park, C.L., \& Folkman, S. (1997). Meaning in the context of stress and coping. Review of General Psychology, 1(2), 115-144.

Parker, J.D.A., \& Endler, N.S. (1996). Coping and defense: A historical overview. In M. Zeidner \& N.S. Endler (Eds.), Handbook of Coping (pp. 3-23).

Pearlin, L.I., \& Schooler, C. (1978). The structure of coping. Journal of Health and Social Behavior, 19(1), 2-21.

Phillips, D. (Ed.). (1998). Heroes: 100 stories of people living with kidney failure. Toronto: Grosvenor House Press.

Pollock, S.E., Christian, B.J., \& Sands, D. (1990). Responses to chronic illness: Analysis of psychological and physiological adaptation. Nursing Research, 39(5), 300-304.

Rosenbaum, E.H. (1982). Living with cancer. New York: Mosby.

Sanson-Fisher, R., Girgis, A., Boyes, A., Bonevski, B., Burton, L., \& Cook, P. (2000). The unmet needs of patients with cancer. Cancer, 88, 217-225.

Singer, P.A., Margin, D.K., \& Kelner, M. (1999). Quality end-of-life care: Patients' perspectives. Journal of the American Medical Association, 281, 163-168.

Steele, R., Fitch, M.I., Alderson, D., Barrow, K., Hurst, N., \& Doyle, C. (2004). Measuring supportive care needs of women with gynecologic cancer. Supportive Care in Cancer, 12(6), 411.

Supportive Care Steering Group. (2004). Supportive care for cancer patients: A forum on collaboration (Greater Toronto Area). Toronto: Author.

Taylor, S.E. (1983). Adjustment to threatening events: A theory of cognitive adaptation. American Psychologist, 38, 1161-73.

Thompson, S.C., \& Collins, M.A. (1995). Applications of perceived control to cancer: An overview of theory and measurement. Journal of Psychosocial Oncology, 13(1/2), 11-26.

Weisman, A.D. (1979). Coping with cancer. New York: McGrawHill.

Whelan, T.J., Mohide, G.A., Willan, A.R., Arnold, A., Tew, M., Sellick, S. et al. (1997). The supportive care needs of recently diagnosed cancer patients attending a regional cancer centre. Cancer, 81, 1518-1524.

Yates, P. (1999). Family coping: Issues and challenges for cancer nursing. Cancer Nursing, 22(1), 63-71.

Zabora, J.R., Blanchard, C., \& Smith, E.D. (1997). The prevalence of psychological distress across the disease continuum. Journal of Psychosocial Oncology, 15, 75-87.

Zabora, J., BrintzenhofeSzoc, K., Curbow, B., Hooker, C., \& Piantadosi, S. (2001). The prevalence of psychosocial distress by cancer site. Psycho-oncology, 10(1), 19-28.

Zabora, J.R., Loscalzo, M.J., \& Weber, J. (2003). Managing the complications in cancer: Identifying and responding to the patient's perspective. Seminars in Oncology Nursing, 19(4, Suppl. 2), 1-9. 